\title{
BIRDS
}

\section{SHORT-EARED OWL INVASION AT BEAVERHILL LAKE, AB, WINTER 2005- 2006}

D. LISA PRIESTLEY, Beaverhill Bird Observatory, Box 1418, Edmonton, AB, T5J 2N5, GEOFFREY L. HOLROYD, Canadian Wildlife Service, Rm. 200, 4999-98 Ave, Edmonton, AB, T6B $2 X 3$ and CHUCK E. PRIESTLEY, STRIX Environmental Consulting Ltd., Box 1013, Tofield, AB, TOB 4J0

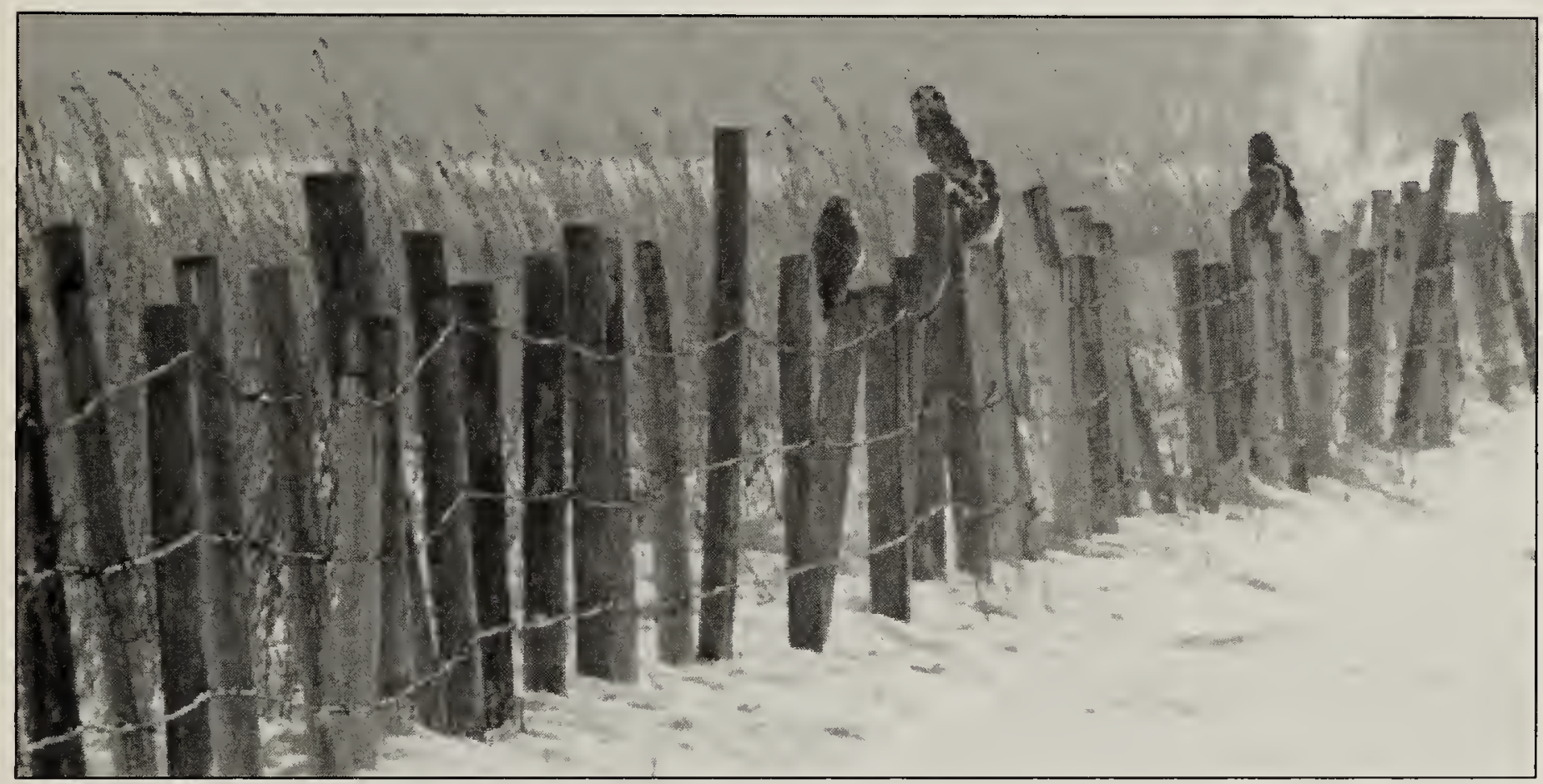

Figure 1. Five Short-eared Owls along a fence line at Francis Point, March 2006

Gerald Romanchuk

The Short-eared Owl (Figure 1) can be found on every continent except Australia and Antarctica. ${ }^{5}$ It occurs in open habitats during the breeding and non-breeding seasons. In Canada, Short-eared Owls breed across the north temperate zone in all provinces and territories, but are most common along the Arctic coast and in Alberta, Saskatchewan, and Manitoba. ${ }^{20}$ In those provinces, they occur mainly in southern, non-forested grassland areas, and in Alberta are most common in the Grassland Natural Region. 15,17,12,8

Short-eared Owls exhibit a variety of movement patterns in different parts of their range. In northern Europe they tend to be migratory whereas in southern Europe they are usually yearround residents. ${ }^{12}$ A similar pattern is thought to exist in North America. In addition to these variations, Shorteared Owls exhibit nomadism across their range. ${ }^{19}$ Many individuals wander widely both seasonally and annually in search of resources..$^{20}$ They travel long distances searching for high densities of small mammals during both the breeding season and winter. Large numbers of Short-eared Owls may roost together in areas where food is abundant ${ }^{5}$ and they tend to be gregarious, forming communal roosts 


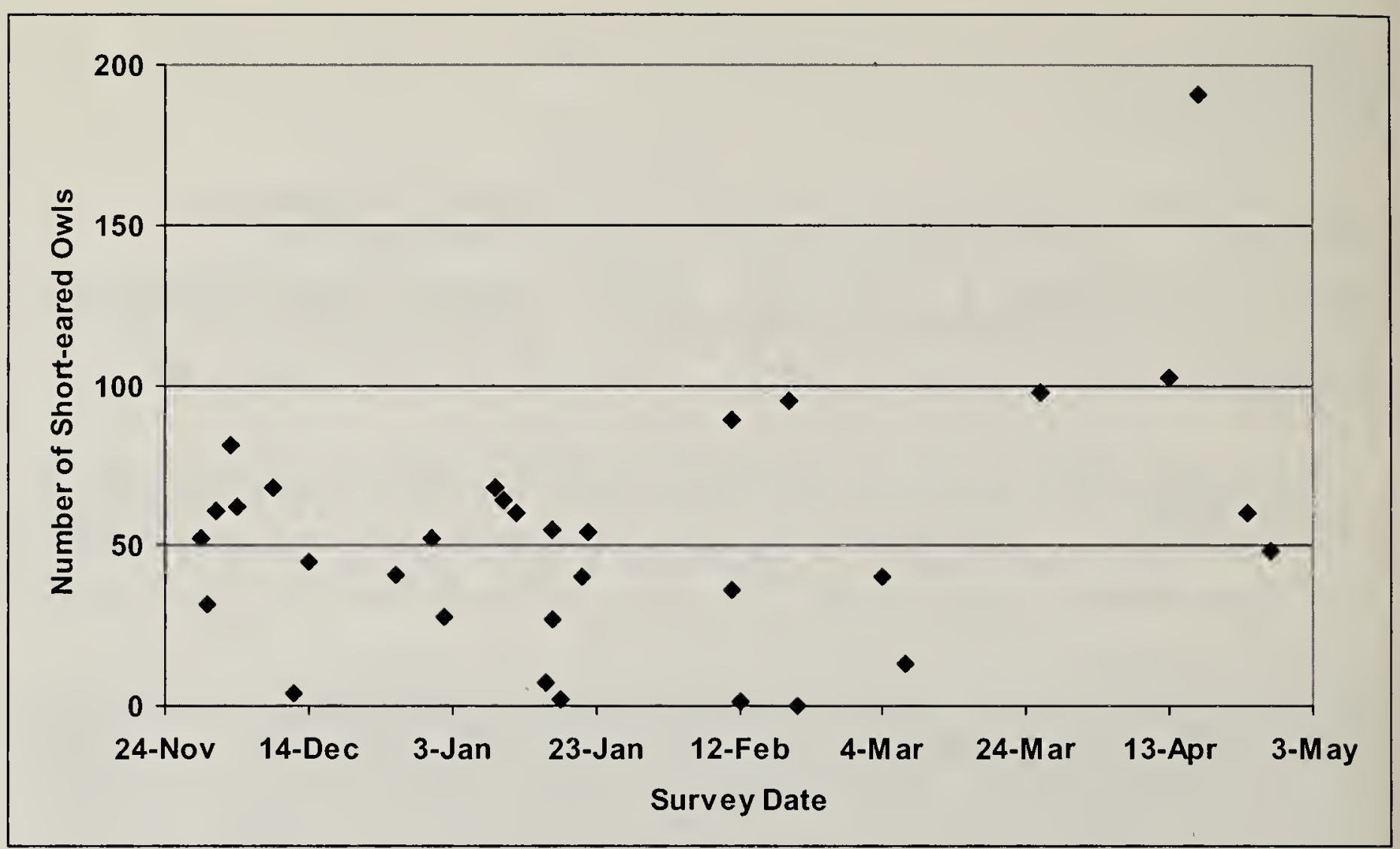

Figure 2. The maximum number of owls counted on each survey day between November 29, 2005-April 27, 2006.

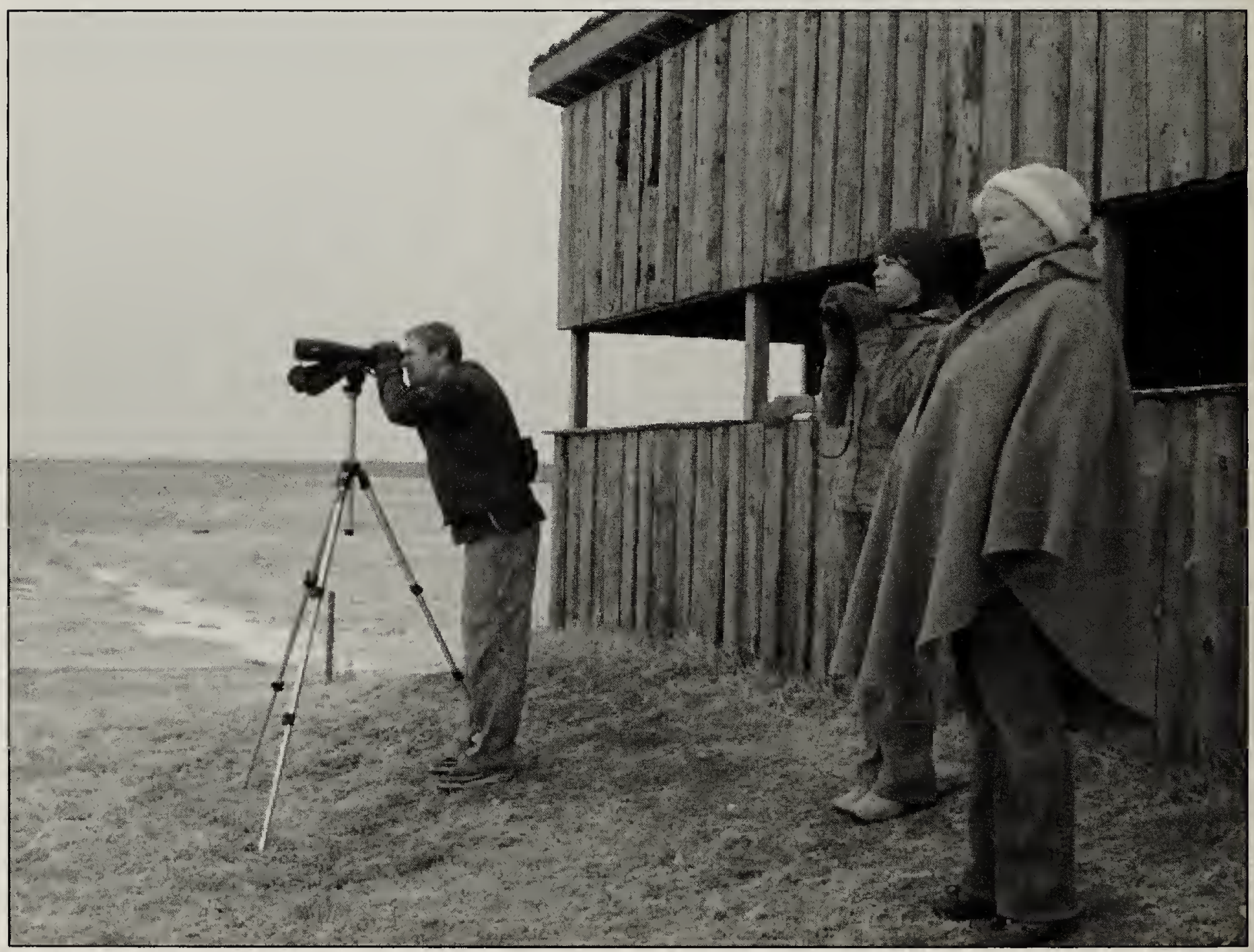

Figure 3. Tyler and Logan Flockhart, and Lisa Priestley (8 months pregnant) at Francis View Point, Beaverhill Lake, New Year's Eve 2005. Chuck Priestley 
in winter. ${ }^{7}$ In fall 1931, Farley (in Bent ${ }^{5}$ ) reported an invasion of 'thousands' of Short-eared Owls that ate 'mice' that thrived in grain shocks in central Alberta. He only documented 24 seen on December 31 near Camrose and 116 counted by John W. Russell in 16 days between November 26, 1931 and February 5, 1932. While we cannot substantiate his estimates of 'thousands,' clearly an invasion of Short-eared Owls occurred that winter.

In 1991, the Short-eared Owl was on Alberta's Green List, signifying that it was a species not believed to be at risk in the province. ${ }^{1}$ The species was moved to the Blue List in 1996 because it was felt that the species may have been at risk in Alberta. ${ }^{2}$ In 2001, the Short-eared Owl was designated as 'May Be At Risk', due to declines in all prairie provinces and other parts of the North American range. Causes of population declines are unknown. The irruptive nature of the species makes trend assessments extremely difficult. ${ }^{3}$ The Short-eared Owl continued to be classed as 'May Be At Risk' in 2005. The Committee on the Status of Endangered Wildlife in Canada (COSEWIC) listed the Short-eared Owl as 'Vulnerable' (now called 'Special Concern'). ${ }^{6}$ After a review in 2007, the species maintained its 'Special Concern' status. ${ }^{20}$

On 29 November 2005, the first author (DLP) was walking along the south shore of Beaverhill Lake (532 23' N, $112^{\circ}$ $36^{\prime}$ W) near Francis Point, a well-known wildlife viewing site. In 2005, the water levels at Beaverhill Lake were low and the water's edge was a few miles north of Francis Point. As DLP proceeded north toward the high water line, she heard the call of a Short-eared Owl in the distance. When the dry lake bed was scanned with binoculars from Francis Point viewing blind, 52 Short- eared Owls could be seen flying and hunting. Over the next few days, the owls continued to be present in high numbers. An e-mail was sent to a local bird watching listserve (Alberta Bird) to inform local bird enthusiasts. Subsequently, many birders went to Francis Point to see the owls. We requested that the birders send us the following information: date of observation, where observations took place, time spent observing, number of owls observed, type of optics used. When we started to receive the data, it became apparent that an unusual event was occurring at Beaverhill Lake because a large number of owls were observed for a long period of time in a small area. The main objective of this paper is to document the Short-eared Owl invasion that occurred during the winter of 2005-2006 at Beaverhill Lake and to explore the possible cause(s) of this event.

We compiled 46 sightings covering 29 days between 29 November, 2005 and 27 April, 2006. All observations were made looking north from the Francis Point blind (see map $^{10}$ ). Observers scanned across the dry lake bed from east to west or west to east. A few observers also walked north onto the dry lake bed, but most observers did not venture past the old south shore of the lake. One or more of the authors were present on 30 of the 46 sightings (Figure 3 ). The other 16 sightings were submitted by several birders whose names are listed in the acknowledgements.

The number of owls counted was highly variable (Figure 2). The highest number of unique individual Shorteared Owls reported at one time from one point was 191 (17 April) and lowest number was 0 (20 February). However, the monthly maximum counts were relatively constant. The maximum 
counts were 81 on 3 December 2005, 68 on 9 January, 95 on 19 February, and 98 on 26 March. Despite this, we found that the average number of owls observed each day increased throughout the winter of 2005-06 ( $r=$ $0.39, P<0.01)$.

This increase in average number of owls throughout the winter was likely a function of this species' nomadic lifestyle. When Short-eared Owls were passing through the Beaverhill Lake area during the autumn they may have stayed because of the high prey density. Records of this number of Short-eared Owls in one area are rarely documented in North America. As many as 200 owls roosted together in California where food was abundant $\left(\right.$ Tyler in Bent ${ }^{5}$ ). There were 650 owls in January and February 2003 in France, including six roosts each with 50 to 65 owls. ${ }^{9}$ Before this concentration was reported, the largest Short-eared Owl roosts in France had not exceeded 20 birds. In the Netherlands, 2000 owls concentrated during a vole plague (Voous 1988 in Holt and Leasure ${ }^{12}$ ).

Beaverhill Lake has been drying out over the past few years, with 2005 being the driest year since the early 1950s. In the summer of 2005, Foxtail Barley (Hordeum jubatum) covered extensive portions of the dry lake bed. The microtine populations, particularly Meadow Vole (Microtus pensylvanicus) increased in number, presumably in response to the huge amount of seeds available. In addition, lower snowfall resulted in shallow $(<10 \mathrm{~cm})$ snow cover until March 2006. A Short-eared Owl breeding study that took place during 1977-1987 in western Finland reported that the number of nesting Short-eared Owls and the number of fledglings produced was positively correlated with spring density of Microtus voles. ${ }^{12}$ In addition, they reported that Short-eared Owls immigrated rapidly into their study area when microtine densities increased and emigrated rapidly when densities decreased. ${ }^{13}$

Owls were observed foraging at all times of day but were more frequently observed during the 60-minute period before civil twilight. ${ }^{18}$ Civil twilight is the time period when the sun has dropped 6 degrees beneath the western horizon; it is the instant at which there is no longer sufficient light to see objects with the unaided eye. In contrast, the number of owls observed at Beaverhill Lake varied throughout the day. Counts were made between 11:00h and 20:00h during the winter. Since sunset varied considerably throughout the observation period, we transformed the time that owls were observed into the number of minutes observations were made before sunset. We were then able to investigate whether the number of owls observed was related to the time of day relative to sunset (Figure 4). There was no linear relationship between number of owls observed and time of day $(P=$ 0.94 ). On 3 December, 17 owls were observed at $12: 15 \mathrm{~h}$, the number rose to 81 at $14: 15 \mathrm{~h}$ and by $15: 00 \mathrm{~h}$ only 29 were seen. Although this was only on one day, it did not follow the pattern documented by Swengel and Swengel. ${ }^{18}$ On 26 December at 15:00h hours, 24 owls were counted in one pass, but when a Snowy Owl flew across the lake some previously undetected Short-eared Owls were flushed and the count increased to 41 at $15: 15 \mathrm{~h}$. It is apparent that several factors affect the number of owls that are visible from one location.

Observer biases may have increased the variation in the data because the counts were made by many people. Another variable in the counts could be 


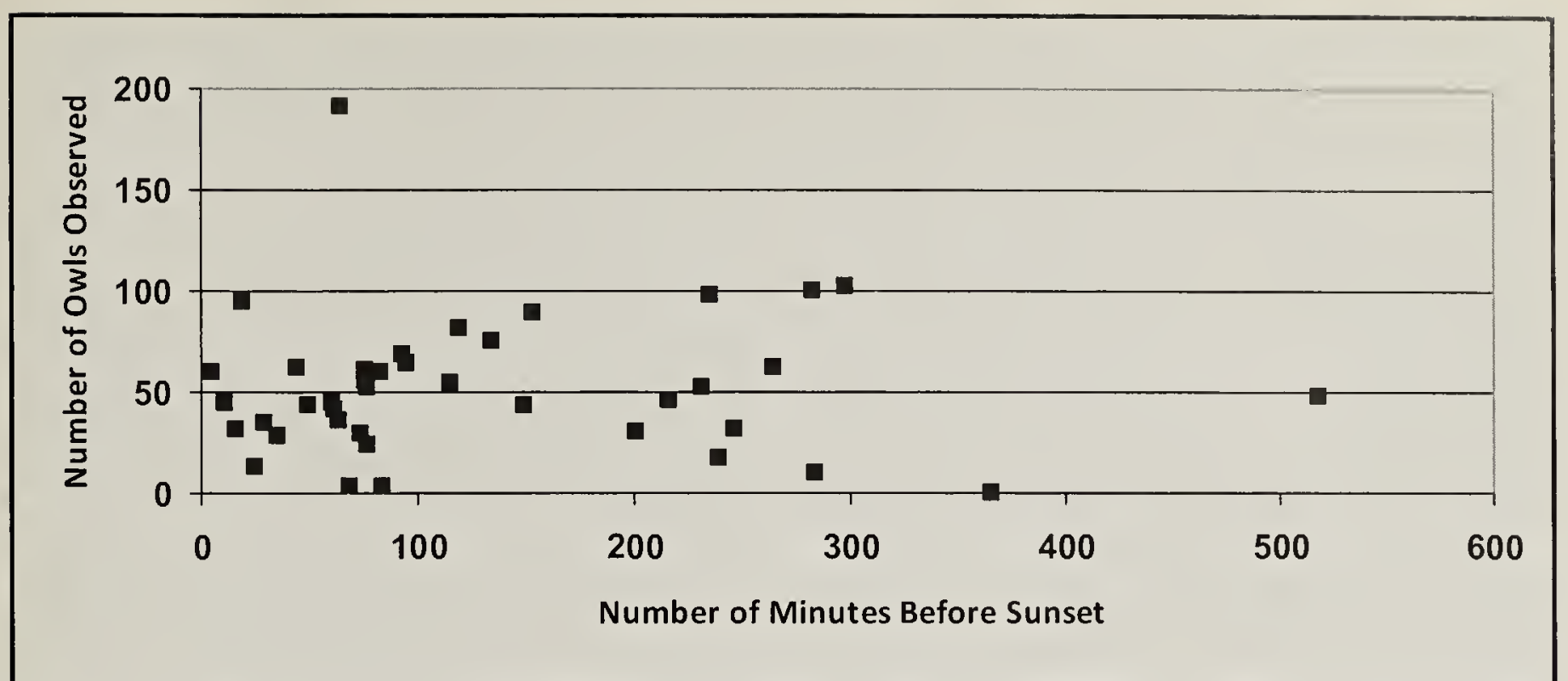

Figure 4. Number of owls recorded versus time to sunset $(=0)$ observed, winter 2005-06 at Beaverhill Lake.

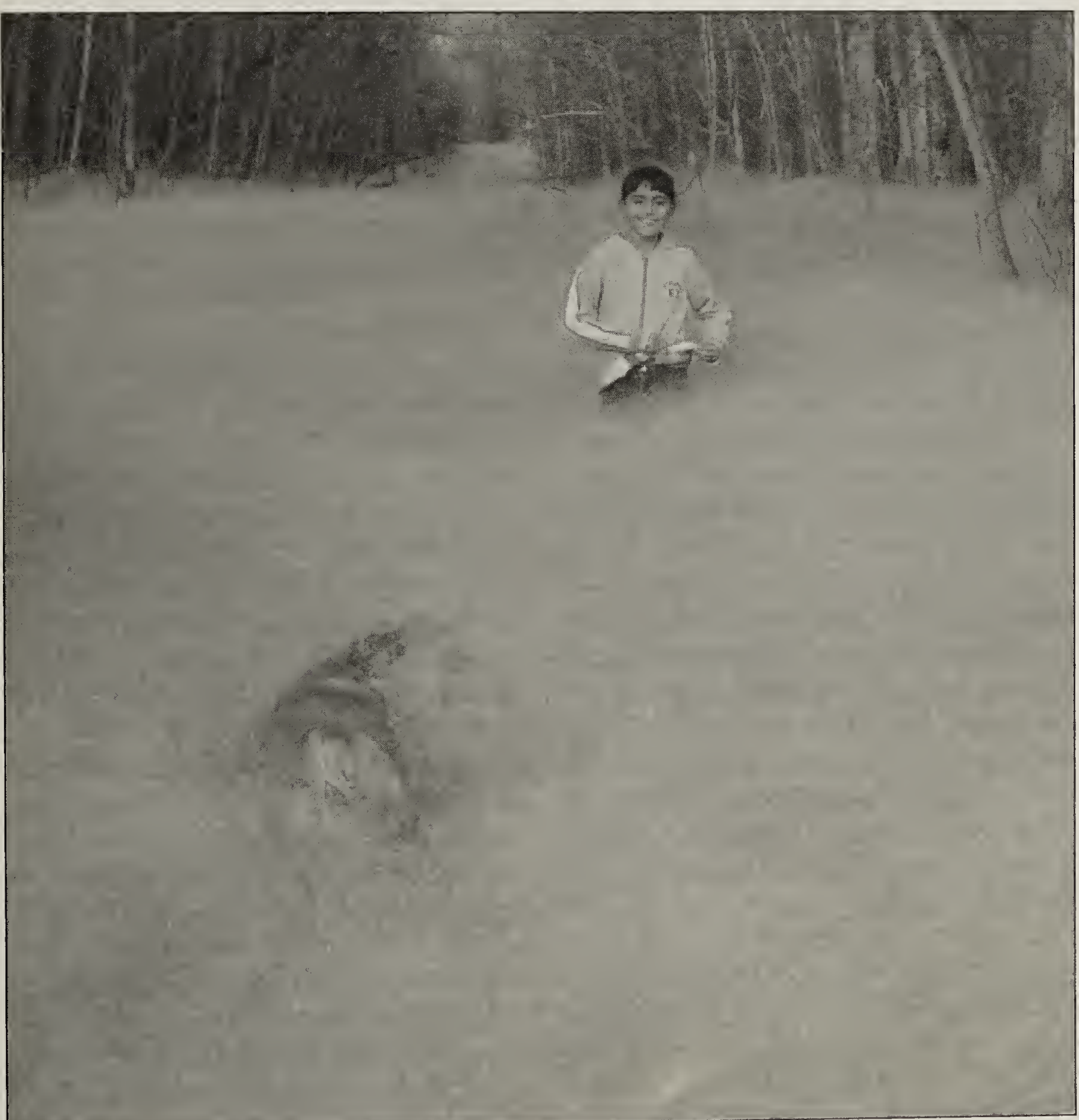

Figure 5. Stephie Valdez and Buttons standing in Foxtail Barley seed piles on the southeast corner of Beaverhill Lake, November $2005 . \quad$ Lisa Priestley 
uneven distribution of owls over the lake bed area. On December 3, when the number of owls observed north from Francis Point varied from 17 to 81 through the afternoon, Gerry Beyersbergen saw none from Mundare Beach, on the east side of Beaverhill Lake approximately $10 \mathrm{~km}$ to the northeast of Francis Point. A number of other people who searched other portions of the lake throughout the invasion period did not find any owls. Clearly the distribution of Short-eared Owls was not even across the lake or in the general vicinity of the lake area. The most likely reason that the owls were concentrated along the southern shore of the lake is that prey density was highest there. In November, a staggering number of Foxtail Barley seeds blew down to the southern shore of the lake (wind direction is predominantly from the northwest). In many places seed piles were more than $1 \mathrm{~m}$ high (Figure 5). The influx of these seeds likely fueled the large increase to the small mammal population in that area.

Other species of raptors were also drawn to the area by its abundant food supply. Species seen around Francis Point and the south end of the lake included Snowy Owls (Figure 6), Northern Harriers, Rough-legged Hawks, and a Great Horned Owl. Snowy Owls and Rough-legged Hawks were observed on many visits throughout the winter. The most impressive multispecies days were 17 April (191 Shorteared Owls, four Red-tailed Hawks, 25 Northern Harriers, two Rough-legged Hawks, and one Snowy Owl), and 24 April (60 Short-eared Owls, two Redtailed Hawks, 10 Northern Harriers, and three Rough-legged Hawks). The Red-tailed Hawks and Northern Harriers were spring migrants, not overwintering raptors.
Other sightings of Short-eared Owls in Alberta for winter 2005-06 that we received include:

1 December -4 individuals, west side of Egg Lake, north of St. Albert, (Dan Stoker)

16 December -3 individuals, west side of Egg Lake, north of St. Albert (Dan Stoker)

17 January - 4 individuals, Big Lake Interpretive trail, St. Albert (Dan Stoker) 24 January - 2 individuals, Big Lake Interpretive trail, St. Albert (Dan Stoker) 13 March - 1 individual, west side Egg Lake, north of St. Albert (Dan Stoker)

13-14 March - 1 individual, Hwy 9 near Richdale, east of Hanna (Royce Howland)

26 February - 1 individual, northwest corner of Frank Lake, $50 \mathrm{~km}$ SSE of Calgary (William Wilson)

27 February -2 individuals, near Hanna (John Carpenter)

These records indicate there were no concentrations of Short-eared Owls at these locations in winter 2005-06, thus showing that there appear to have been no other invasions in the region.

Finally, in spring and summer 2006 we searched for breeding Short-eared Owls along the south shore of Beaverhill Lake and were unable to locate any nests. They are known to breed on site regularly. ${ }^{14} \quad$ Up to six Short-eared Owls were reported flying near the Beaverhill Lake Natural Area by Beaverhill Bird Observatory staff throughout the summer months. In September and October 2006, up to seven Short-eared Owls were observed along the road running east-west on the south end of the lake, which could possibly have been a family of owls. No invasion was observed at Beaverhill in the winter of 2006-07 or 2007-08. Over $20 \mathrm{~cm}$ of snow arrived in 


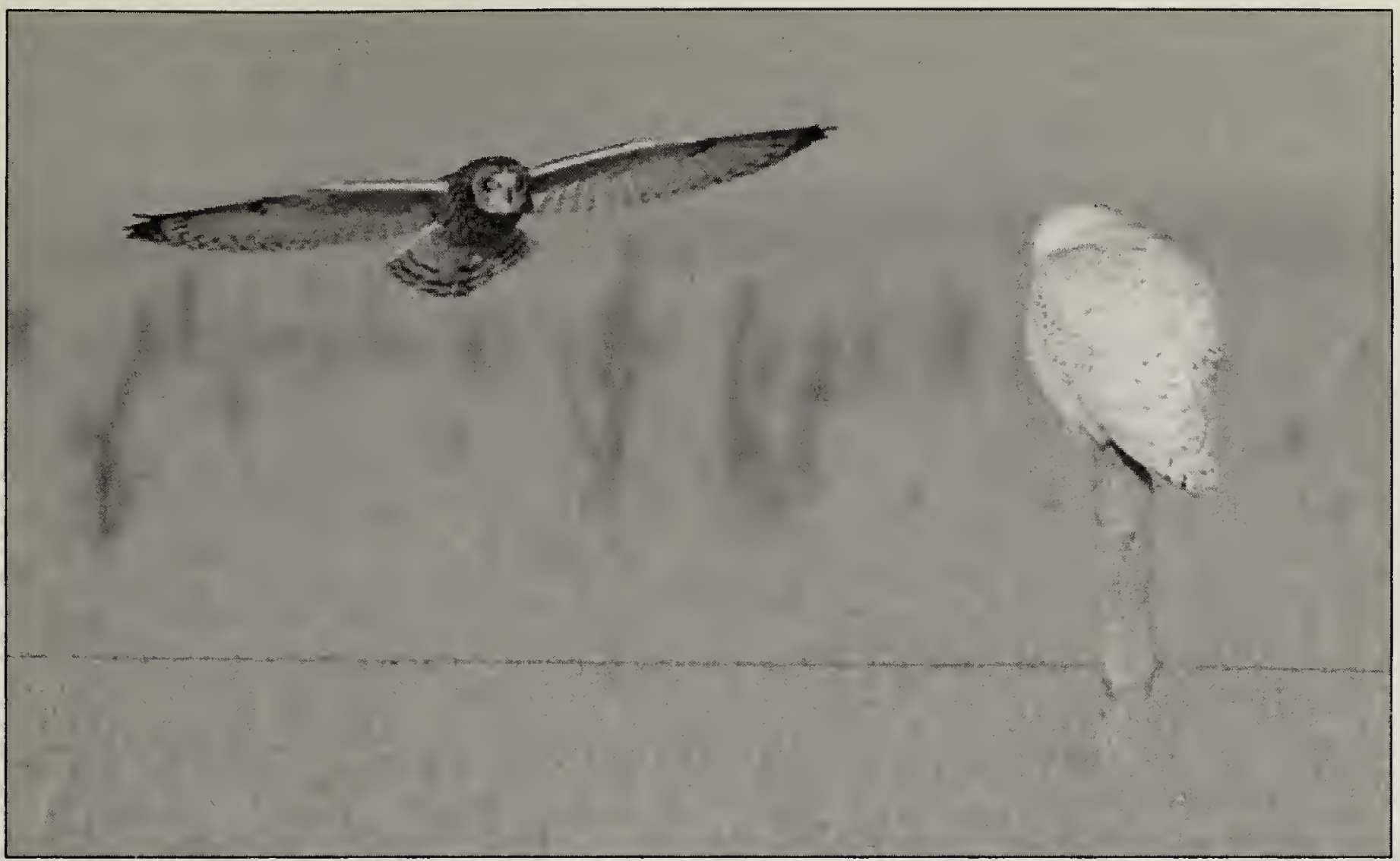

Figure 6. Short-eared Owl diving at a Snowy Owl, Francis Point, Beaverhill Lake Gerald Romanchuk

November 2006 which may have prevented owls from foraging efficiently, and Foxtail Barley seeds were not as prevalent in both winters.

The large variation in the numbers detected between and within days demonstrates how difficult Short-eared Owl monitoring can be. This species is not well monitored by existing large scale surveys such as the Breeding Bird Survey and Christmas Bird Count. Even though there are concerns about population declines of Short-eared Owls, there are no management efforts in the United States, and only Newfoundland and Labrador have a plan in Canada. ${ }^{16} \mathrm{~A}$ dedicated, longterm monitoring program needs to be implemented to better understand the Short-eared Owl. ${ }^{20}$ Documenting invasions is critical to our understanding of where, when and why they occur. Moreover, satellite telemetry will further help us understand the movement patterns of individuals ${ }^{11}$ and may help us discover other invasion locations.

\section{Acknowledgments}

Thanks to all the people who contributed their Beaverhill sightings: Gerry Beyersbergen, Karen Dean, Tyler and Logan Flockhart, Deb and Royce Howland, Andrew Iwaniuk, Dwight Knapik, Richard Krikun, John Moore, Jim Morrison, Carole Newton, Paul Newton, Jasmine Newton, Gill Priestley, Sam Priestley, Gerald Romanchuk, Martin and Patricia Sharp, Peter Stahl, Brian Stephens, Helen and Phil Trefry, William J.F. (Bill) Wilson, and Walter Yanowsheski. Thank you to Chris Fisher for forwarding our request for sightings to Alberta Bird Listserve. We also thank Gerald Romanchuk for providing photos. Helen Trefry provided comments on an earlier draft of this paper. Support from Beaverhill Bird Observatory is greatly appreciated.

1. ALBERTA FISH AND WILDLIFE. 1991. The Status of Alberta Wildlife. Alberta Forestry, Lands, and Wildlife, Edmonton, $A B$.

2. ALBERTA ENVIRONMENTAL PROTECTION. 1996. The Status of Alberta Wildlife 1996. Alberta Environmental Protection, Wildlife Management Division, Edmonton, $\mathrm{AB}$. 
3. ALBERTA SUSTAINABLE RESOURCE DEVELOPMENT. 2000. The General Status of Alberta Wild Species 2000. Alberta Sustainable Resource Development, Edmonton, $\mathrm{AB}$.

4. ALBERTA SUSTAINABLE RESOURCE DEVELOPMENT. 2006. The general status of Alberta wild species 2005. Alberta Sustainable Resource Development, Edmonton, AB.

5. BENT, A.C. 1938. Live Histories of North American Birds of Prey, part 2. Dover Reprints 1961 of Smithsonian Institution US National Museum Bulletin 167.

6. CADMAN, M. D., and A. M. PAGE. 1994. Status Report on the Short-eared Owl (Asio flammeus) in Canada. Committee on the Status of Endangered Wildlife in Canada, Ottawa, ON.

7. CLAYTON, K.M. 2000. Status of the Shorteared OWl (Asio flammeus) in Alberta. Alberta Environment, Fisheries and Wildlife Management Division, and Alberta Conservation Association, Wildlife Status Report No. 28, Edmonton, AB.

8. FEDERATION OF ALBERTA NATURALISTS. 2007. The Atlas of Breeding Birds of Alberta, a Second Look. Federation of Alberta Naturalists, Edmonton, AB. 626 pp.

9. FEUVRIER, B., D. MICHELAT, and M. VASLIN. 2005. Influx of short-eared owl in France, winter 2002-2003. Ornithos 12(5): 261-268.

10. FLOCKHART, T. 2001. Rare or unusual bird sightings for Beaverhill Lake, Alberta 1996-2000. Blue Jay 59(1): 22-40.

11. HOLROYD, G.L., and H. TREFRY. 2008. The travels of a Short-eared Owl equipped with a satellite transmitter in Canada. Blue Jay 66(1): 28-30.
12. HOLT, D. W., and S.M. LEASURE. 1993. Short-eared Owl (Asio flammeus). In The Birds of North America, No. 62 (A. Poole and F. Gill, eds.). The Academy of Natural Sciences, Philadelphia, PA.; The American Ornithologists' Union, Washington, DC.

13. KORPIMAKI, E. and K. NORRDAHL. 1991. Numerical and functional responses of kestrels, short-eared owls, and long-eared owls to vole densities. Ecology 72(3):814-826.

14. PRIESTLEY, L. 2004. Discovering of a shorteared owl nest at Beaverhill Lake, Alberta. Edmonton Nature News 2(1): 17-18.

15. SALT, W.R., and J.R. SALT. 1976. The Birds of Alberta. Hurtig Publishers, Edmonton, AB.

16. SCHMELZER, I. 2005. A Management Plan for the Short-eared Owl (Asio flammeus flammeus) in Newfoundland and Labrador. Wildlife Division, Department of Environment and Conservation. Corner Brook, NL.

17. SEMENCHUK, G. (ed.) 1992. The Atlas of Breeding Birds of Alberta. Federation of Alberta Naturalists, Edmonton, $A B$.

18. SWENGEL, S.R. and A.B. SWENGEL. 2002. Variation in detection of short-eared owls in Wisconsin and the Midwest. Passenger Pigeon 64(4): 255-270.

19. VILLAGE, A. 1987. Numbers, territory-size and turnover of short-eared owls Asio flammeus in relation to vole abundance. Ornis Scandinavica 18:198-204.

20. WIGGINS, D.A. 2007. Update COSEWIC Status Report on Short-eared Owl Asio flammeus. Draft Report prepared for the Committee on the Status of Endangered Wildlife in Canada.

"The strangest [nest] building material of all is that of the edible swiftlet, an Asian species that builds a small, half-circular cup from strands of its own dried saliva (the nest is the main ingredient in bird's-nest soup)." Scott Weidensaul, The Birder's Miscellany, p.46 